\section{【エ 業薬品】}

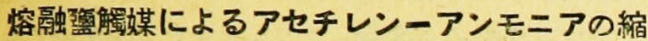

合反應 熔融監化亞鋁の存在の下にア七チレンとアン モニアの縮合岂行ひ，ピリデンを合成せんとした。この

際 (1) 友び (2) の反應ゔ豫想されるが，

$$
\mathrm{G}_{2} \mathrm{H}_{2}+\mathrm{NH}_{3} \rightarrow \mathrm{CH}_{3} \mathrm{CN}+\mathrm{H}_{2} \text { (1) }
$$

- $3 \mathrm{C}_{2} \mathrm{H}_{2}+\mathrm{NH}_{3} \rightarrow \mathrm{C}_{5} \mathrm{H}_{5} \mathrm{~N}+\mathrm{CH}_{4}$ (2)

主反應生成物はアセトニトリルで, 純度 $75 \sim 85 \%$ の のが約 $60 \%$ の收率で得られ，(2) の反臀交殆ど起らな

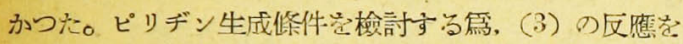
渘想して, 觸媒濃度, 溫度を變へて,

$$
\mathrm{CH}_{3} \mathrm{CY}+2 \mathrm{C}_{2} \mathrm{H}_{2}+\mathrm{H}_{2} \rightarrow \mathrm{C}_{5} \mathrm{H}_{5} \mathrm{~N}+\mathrm{CH}_{4}
$$

モル比が $\mathrm{CH}_{3} \mathrm{CN}: \mathrm{C}_{2} \mathrm{H}_{2}: \mathrm{H}_{2}=1: 2: 1$ のガスを反㮣 させたが，ビリヂンは得られなかつた。(1)の反應は烈

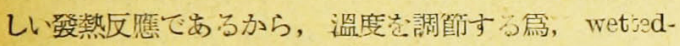
wall column 中で反應ガスと熔融整を: count r-current に流し反應を行つた。触媒として種々の愹饳照の成

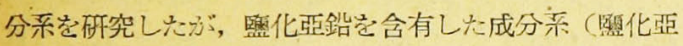
鋁 $40 \%$ に對し監化ナトリウム $60 \%$ オ゙最直）が最も活 性な觸媒である。 $440 \sim 550^{\circ} \mathrm{C}$ の溫度範園で, 液爿生成

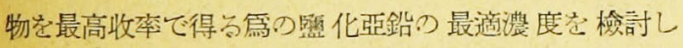

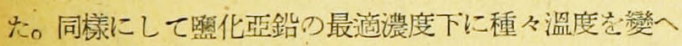
て實驗を行ひ最適溫度夌檢索した。その結果 $510^{\circ} \mathrm{C}$ に

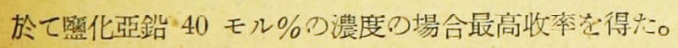
$430^{\circ} \mathrm{C}$ の温度では監化亞鉛にアンモニアが反應して, 安 定な複盟を生成する篇全然反應は起らなから。この際 整化アルカリが其存すると, 顯著に觸煤つ活性度び上䒜 する事仯認められた。アンモニアに對するアセチレンの

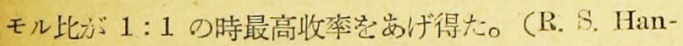
mer and S. Swann, Jr., Ind. Eng. Che n., 41, 325 (1949)）（淺原）

\section{染} 料】

1ーブロムー2ーメチルアンスラキノン 2-ineth-

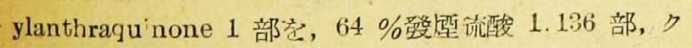
ロルズルホン酸 2.1 部及 1-3romo-2-methyl anthraquinone 0.01 部の混合溶液に攪拌しながら徐々に源加す

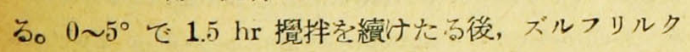

ロリト 1.216 部及び息素 0.361 部蛋加へ反應溫度索 $25^{\circ}$ に上䒜せしめ, $25 \sim 30^{\circ}$ て $40 \mathrm{hr}$ 㩭䢁す。反應混

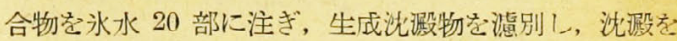
水洗し酸学除く。更に $2 \% \mathrm{NaOH}$ て虎理し, 後水洗しア ルカリ穵除く。かくて染料中間體としてて有用な1-bromo2-methylanthraquinone 1.34 部管得る。ブロム化ふで ルフリルクロリドの代りに腑素を用ふるるも艮い。(E. I du Pont, U. S. P. 2,396,989 ; C. A., 4), 4227 (1946), (內木)

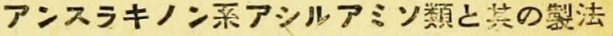

1-benz ımido-4-(p-arboxyphenylamino) anthraquin-

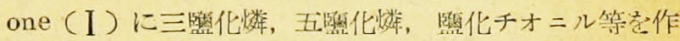
用せしめて, 其のカルボキシ基壳一COCl 基に變へ，例 酸劑つ存在で第 1 級りアミノアンスラキノン類さ縮合 也しめて、クロル反 $\mathrm{NaCO}_{3}$ に堅牢な建染染料う得ら

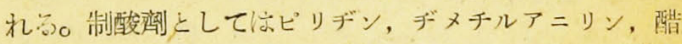

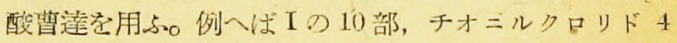
部, ニトロベンゾール 100 部圶 $120^{\circ}$ で $1 \mathrm{hr}$ 反應せし めたる後, 1-amino-5-benzamidoanthraquinone 7.4 部 と $130 \sim 140^{\circ}$ で $1 \mathrm{hr}$ '加熱すれれば木棉をオリーブ色に

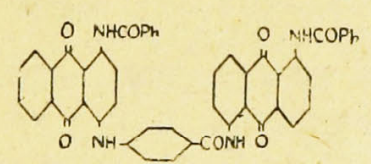
染める染料卷得る。文 1-benzamido - 4- (ocarboxyphenylamino) -anthraquinone ぶ゙用 ーひられる。其他 I に 1-amino-4-phenyl-amino-anth-

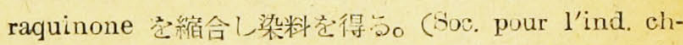
im. á Bale, U. S. P. $2,392,6633$; C. A., 4), 2642 (194 6)) (內木)

アンスラキノン誘導體 $\bigcup_{5} \sim \bigcup_{1}$, アルコオキシア ミン類を， $a$ 位に置換基冷有し，更に枯にアシル基又は ハロゲンを有するアンスラキノン類上反應せしめて，染 料中間體として有用な化合物堂得う。例へば 2-aminoethyl-2-methoxyechylether (I) 80 -部，キニザリン （II） 10 部、リューコキニザリン 10 部，イソブチルア ルコール 1.59 部か混合物を: $5.5 \mathrm{hr}$ 加熱後, ピリヂン 1 部 を加一沸㫮にて空氣を通じ， 1,4-つis [2-(2-methoxyethoxy) ethylamino] anthrajuinone ( II) 娄得る。こ

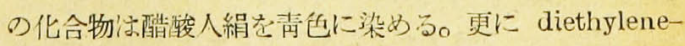
glyeol methyl-2-amino-ethyl ether む』、1ークロ、 
ラキノソ (IV)，4ーブロモー1ーメチルアミノアンスラ キノン又は Na antinraquinone-1-3ulfonate と作用せ 乙め有用な赤色染料を得る。他㢣例あり。(Imp. Chem. Ind., U. S. P. $2,383,236$; C. A., 4], 216 (1946)) (队朴)

アンスラキノン誘導體 一般式下記のアンスラキノ ン類に，2 分子のメチルアミン又は2ーヒドロオキシェ

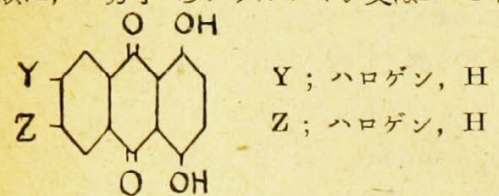

チルアミンを作用せしめ, 必要める時は空氣酸化して有 機溶渓，可望性物質及醋酸繊維素つ着色劑として適當な 色素志得る。例へば 6ークロロリューコキリザリン（Ｉ） 10 ， モノエタノールアミン $15 \mathrm{~g}$, アルコール $65 \mathrm{~g}$ の混 合物を $80^{\circ}$ に加熱し後空氣酸化して 1,4-bis (2-hydroxyethylamino)-6-chloro-anthraquinone を得る。此

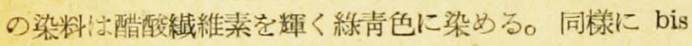
(2-hydroxyethylamino)-6,7-dichloroanthraquinone, : 1,4 bis (methylamino)-6-chloroanthraquinoneを得る。 (Fandoz I.td., B. P. 558,386 ; C. A., 49, 1672(1946)) (队杖)

アンスラキノシ染料 5-amino-2,1 (S)-anthraquinonethiaxanthone を 4,5 位又は 8 位の中 1 ケのべ ンス゚アミド基を有する1ークロ、アンスラキノン類と縮 合せしめ, 生成せるアンスリイミドをニトロベンゾール 又はビリヂン中にて $\mathrm{AlCl}_{3}$ で處理すれば閉環し,一般式

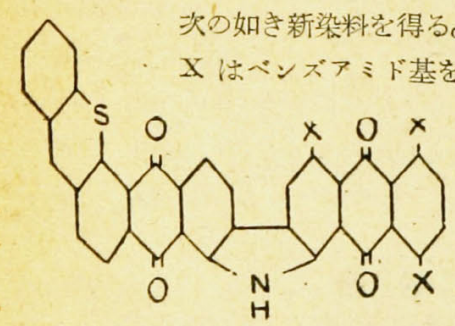

大の如さ新染料を得る。こへに ることは好しい結果を與へる。1ークロロアンスラキノ ン類として, 1-benzamido-4-chloroanthraquinone $う ゙$ 用ひられる。 (E. I. du Pont, B. P. 561,754 ; C. A., 49, 214(1946)) (內木)

アンスラキノン染料 置換基を有するアンスラキ， ン類, 要すればリューコ化合物に $\mathrm{m}$ ーアミノベンジル アルコールスはその核置換誘導體を縮合せしめて染料を 得る。例へば 1 メチルアミノー4ーブロムアンスラキ ノン $32 \mathrm{~g}, \mathrm{~m}$ アミノペンジルアルコール $18.5 \mathrm{~g}$, エチレ ングリコール・モノェチルェーテル $100 \mathrm{~g}$, 無水醋酸加里
$15 \mathrm{~g}$ ，硫酸銅 $0.5 \mathrm{~g}$ の混合物を $137^{\circ}$ に $8 \mathrm{hr}$ 加熱し，後 アルコール200るで稀釋し冷後滤過す。粗成物をニトロ ペンゾールより再結晶し 1-methylamino-4-(m-hydroxymethylanilino) anthraquinone (m.p. $179^{\circ}$ )を得る。 本染料な醋酸纎維素字青線色に染める。其他數例を發表 してるる。 (E. I. du Pont de Nemours \& Co., B. P. 560,817 ; C. A., 4), 3907 (1946)) (內木)

アンスラキノン染料 アルコオキシアルキルアミ， 基及ぴヒドロオキシアルキルアミノ基を有するアンスラ キノン誘導體が䋐維素エステル類の染色に用ひられる。 此の染料は熱及び蒸氣に對し安定て捺染に用ひ得る。ヒ ドロオキシェチルアミン 256g, 2-methoxyisopropylamine $354 \mathrm{~g}$ の混合物をリューコキニザリン $388 \mathrm{~g}$, キニザリ ン $576 \mathrm{~g}$, 重畺 $70 \mathrm{~g}$, ブタンール $41 \mathrm{~g}$ の混合物中に $60^{\circ}$ にて 加へ, 更に $12 \mathrm{hr}$ 還流下に㷫したる後水を加へ, 硼砂 $280 \mathrm{~g}$ を加へて $2 \mathrm{hr}$ 加熱する。反鷹生成物を $1 \% \mathrm{Na}$ $\mathrm{OH}$ 溶液中に注ぎ, $60^{\circ}$ に加溫し溫時㴔過し不溶性染料 1-(2-hydroxyethylamino) -4- (2-methoxyisopropylaminoanthraquinone (m.p. $170^{\circ}$ ) $775 \mathrm{~g}$ を得る。更に 數種の染料について述へててるる。此等染料は䋐維素エス テル類を青色に染める。 (Fastman Kodak Co., U. S. P. $2,398,454$; C. A., 4], 3907 (1946)) (內木)

アンスラキノン染料 C-aralkyl cycloaliphatic re sidue amine ( I ) (一般式 $\mathrm{NH}_{2} \mathrm{X}\left(\mathrm{CH}_{2}\right) \mathrm{n} \mathrm{Y,} \mathrm{こに}$ $\mathrm{X}=$ cycloaliphatic 残基, $\mathrm{Y}=ア$ リ基, $\mathrm{n}=1,2,3)$ と a 位に第 1 級アミンと作用して置換され得る基を有し,他 にスルフォン基以外の置換基を有するアンスラキノン誘 導體のリューコ化合物 (II) を縮合せしめ，新酸性羊毛 染料ゔ得られる。更に之をスルフォン化して 1〜2 個の スルフォン基を導入する。 I として 2-benzylcyclohexylamine, II としてリューコキニザリンが用ひられる。 例へばリューコキニザリンに trans-2-benzylcyclohexyl amine 希作用せしめ、羊毛䒚線青色に染める染料它得 る。以下數例安り。 (Imp. Chem. Ind. Ltd, B. P. 564,859 : C. A., 40, 4227 (1946)) (內木)

アンスラキノン系染料 一般式下記の如きアンスラ

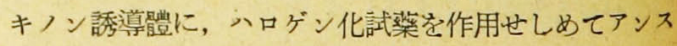
ラキノン系染料ブ得られる。一般には更にスルフォン化 する。例へば 1,4-bis (2,4-dimethyl一6-bromophenylamino)-6-Chloroanthraquinone, 左び對應する 6-bromoanthraquinone の兩者のスルフォン化物は共に羊毛を靑 色に染める。1,4-bis (2,4-dimethyl-6-bromophenylamino)-6,7-dichloroathraquinone, 1-amino-2-bromo4(2,4-dimethy]-6-bromophenylamino)-6(or 7)-chlo- 

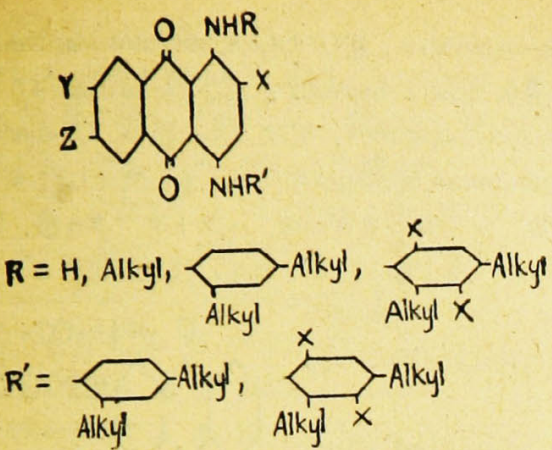

$X=$ halogen, $H$, alkyl, sulfo, cyano

$Y=$ halogen, $H$

$Z=$ halogen, $H$

roanthraquinone のスルフォ认化物名羊毛を青色に染 める。 攴ヂクロル化合物はモノクロル化合物に比し羊毛 を綠色の色調を與へる。(Sandoz Ltd., B. P. 560, 164 ; C. A., 49, 2996 (1946)) (內木)

アンスラキノン染料と其の製造過程 6 位又は 7 位にハロゲンを有し，1 位及 4 位にスルフォン化され たヒドロオキシアルキルアミノ基を有するアンスラキノ 類から羊毛，絹及ナイロンに適する青色染料が得られ る。例人ばリューコ・6-クロロキニザリン 10 部，2アミノー1ープロパノール 8 部, エタノール 50 部岂 $60^{\circ} \sim 80^{\circ}$ で反應せしめ，生成せるリューコ化合物を空 氣酸化し, 1,4-bis (2-hydroxyisopropylamino)-6-chloroanthraquinone を得, 之をスルフォン化してヂスルフ オン酸它得る。6,7-ヂクロロ广ンスラキノンを用ふると きは綠青色染料を得, 又 2-广ミノー1ーブタノールを用ふ れば堅牢度大なる靑色染料夲得る。（Sandoz Ltd., U.S P. $2,386,309$; C. A., 40, 214 (1946)) (内木)

酸に依る浪色に對し堅牢なるアンスラキノン染

料 hydroxylaminoanthraquinóne, aminohydroxyanthraquinone 等のアンスラキノン類のリュー・コ化合物 (II) に，脂肪族アルデヒド類（四）学縮合せしめて,酸 に依る裉色に堅牢て䋐維素誘導體を種々の靑色に染める アンスラキノン染料 (I) を得る。例へば 4,8 ・ヂアミ ノアンスラルヒン支び 4,8一 ヂヒドロキシルアミノアン スラルヒンにホルマリンを縮合せしめて特に有用な青色 染料を得る。本反應は II の 1 モルに對し II の 4 モ ルを縮合せしめるので, II は 4,8 dinitroanthraquinone の如き對應するニトロアンスラキノン類をハイドロサル ヘイトで還元して得られる。(Celanese Corp. of America, U. B. P. $2,368,681$; C. A., 40, 2640 (1946))
(內木)

アンスラキノン染料 5-amino-2,1-N-anthraquinonebenzacridine, 1-benzoylamino-4-chloroanthraquinone, 曹達灰, 及 $\mathrm{Cu}_{2} \mathrm{Cl}_{2}$ をニトロペンゾール中て約 $8 \mathrm{hr}$ 還流下に加熱し, 生成せる $4^{\prime}$-benzoylamino-6,5(N) -benzacridone-1',1 dianthrimide (I) を更に= トロペソゾール中て $\mathrm{AlCl}_{3}$ てて處理し，生じな醋酸学水 水で分解して dianthrimidecarbazole 采のアンスラキ ノン染料を得る。(du Pont., U. S. P. 2,373,817；C. A., 43, 213 (1946)) (队丙)

\section{ニトロアン゙染料スルフォ゙酸 $\mathrm{PhN}=\mathrm{NPhNR}$}

のヒドロキシアルキル誘導體をスルフォン化，ニトロ化 することにより可溶性な醋酸人絹, ナイロン用染料学得 る。例へば $3-\mathrm{NO}_{2} ・ \mathrm{C}_{6} \mathrm{H}_{1} \mathrm{~N}=\mathrm{NC}_{6} \mathrm{H}_{4}-4^{\prime}-\mathrm{NHCH}_{2} \mathrm{CH}_{2} \mathrm{OH}$ 2.9 部を $\mathrm{H}_{2} \mathrm{SO}_{4} 30$ 部に溶し, そに 1.4 部の混酸を -5〜 5゚で作用せしめ，乙の反應混合物を氷上に注ぎ $10^{\circ}$ に達せしめ， $\mathrm{NaC} \perp$ にて需析し染料を赤褐色粉末 $(\mathrm{I})$ と して得る。同栐に $3-\mathrm{NO}_{2}-\mathrm{C}_{6} \mathrm{H}_{4} \mathrm{~N}=\mathrm{NC}_{6} \mathrm{H}_{4}-4^{\prime}-\mathrm{NEtCH}_{2}$ $\mathrm{CH}_{2} \mathrm{OH}$ より褐色染料を得る。又 4 ー ニトロ誘導體から 赤色染料芝得る。 I の 0.5 部岑 $\mathrm{H}_{2} \mathrm{O} 3000$ 部, $\mathrm{Na}_{2} \mathrm{SO}_{4}$ - $10 \mathrm{H}_{2} \mathrm{O} 40$ 部の染浴に醋酸人絹 100 部字 $80^{\circ}$ て $1 \mathrm{hr}$ 镸染し, 水洗, 乾燥すれば黄色に染色される。 (Soc. pour 1'ind. chim. à Bâle ; U. S. P. 2,387,987; C. A., 4), 742 (1946)) (內木)

\section{デー9ーアンスロニリデンエタンよリ得られる建}

染染料 1,2-di-9-anthronylideneethane (I) 及び 1, 2-bis (4-Chloro-9-anthronylidene) ethane せニトロ ベンゾール（II）中で, ベンゾイルクロリイド, アセチ

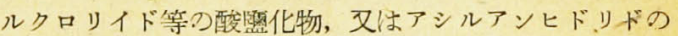
如き酸無水物及び硫酸の如き酸性物質る区應せしめて建 染染料ゔ得られる。例へば I $40 \mathrm{~g}$ ニトロペンゾール $36 \mathrm{~g}$, 無水醋酸 $96 \mathrm{~g}, \mathrm{H}_{2} \mathrm{SO} \mathrm{O}_{4} 32 \mathrm{~g}$ の混合物を $120^{\circ}$ で $1 \mathrm{hr}$ 加 等し, 泠却後滤別し, ニトロベンゾールで洗临し, 更に アルコールで洗湅する。 (Imp. Chem. Ind. Ltd., U. S. P. $2,385,185$; C. A., 4), 215 (1946)) (队木)

繊維性物犋に對する硫化染料 $\mathrm{p}, \mathrm{p}^{\prime}$-di (6-methyl benzothiazoyl)-azobenzene-di (4-thiocyanosulfonanil-ide)（I）を非水溶媒中で硫化曾達と加熱し, 對應する di-(4-mercaptosulfonanilide) 光作り, 空氣酸化して多 硫化物定得る。 I は p, $\mathrm{p}^{\prime}$-di (6-methylbenzothiazoyl) -azobenzenedisulfonylchloride $を$ p-thiocyano-N-methylaniline, $\mathrm{p}$-thioyanoaniline, 2-methoxy-4 thiocyanoaniline, 2,5-dichloro-4-thiocyanoaniline, 及び pthiocyano- $\mathrm{N}$-benzylaniline と共に熱すると得られる。 
106

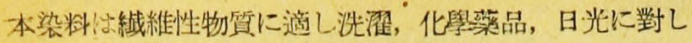
堅暒である (U. S. P. 2,368,658)。 diamino-p,p'-di (6-methylbenzothiazoyl) azobenz’ne よりる硫化染料 ゔ得られる。(Imp. Chem. Ind Lt1.., U. S. P. 2,368,657

\section{A., 4), 216 (1946)) (內木)}

アシスラキノン染料 4-p-phenylazoanilinoanth raquinone 類に登唒硫酸，クロルスルフォン酸苍辞酸溶 媒中で作用せしめて, アンスラキノン系水溶性染料を得 る。こフにアンスラキノン核の 1,5 又は 8 位の中 1 ケにアシルアミ)基壳有し，他の位に置換基学有しない か，或はハロゲンを有し，2 位にハロゲン, メチル基， スルフォン基索有し且つ $\mathrm{p}$-フェニルアジアニリノ基つ 核に水酸基, アルコオキシ基, アミノ基, アルキル基, = ト口基, ハロゲン党有するものとす。例へば 4-2henylazoanilino-1-acetamido-2-methy]-anthraquinone ₹ スルフォン化して赤褐色羊毛用染料を得る。其他鹳例㚣 り。 (Imp. Chem. Ind I.td., B. P. 560,$988 ; C$. A., 49, 4529 (1946)) (內木)

アンスラキノン系酸性羊毛用染料 一般式次の如 き酸性アンスラキノン染料位羊毛を酸性浴て青色に染め

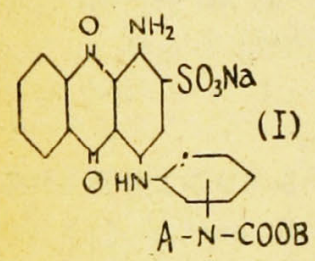
特に日光に堅牢である。 こにA はアルキル基, ヒドロオキシアルキル基 爻はアルコオキシアルキ 几基営示し, Bはメチル 基又はェチル基苍示ず。

1-amino 4 - halogenoanthraquinone-2-sulfonate $K$ aminc-N-alkyl carbanilic asid のメチルェステル, 叉 はェチルェステルを銅觸媒で縮合せしめてIを得る。例 へば Na-1-amino-2-salfo-4-bromcanthraquinone に 层素, $\mathrm{NaHCO}_{3}$ 及 $\mathrm{Cu}_{2} \mathrm{Cl}_{2}$ の水溶液中で 4-amino $=\mathrm{N}$ methylcarbanilic acid のメチルエステルを作用せし めて A，B 共メチル基つI炎得る。 4-amino-N-methylearbanilic acid のエチルエステルを用ふると A はメ チル基，B はエチル基の I を得る。(Allied Chemical \& Dye Corp., U. S. P. $2,400,188$; C. A., 49, 4529 (1946)) (队木)

醋酸人絹用アンスラキノン染料 2 ケ以上のアミ ，基电有するアミノアンスラキノン誘導體 (I) にヂカ ルボン酸無水物（II）を作用せしめ, 部分的にアシル化 し，生成物を Naー 㧘とすることに依り，醋酸人絹を青 又心䋨色に染める染料が得られる。アシル化反應はピリ ジン, ニトロペンゾール,ヂメチルアニリン，0-ヂクロル ベンゾール等の溶媒中で行はれる。Iの例としては， 1 , 4,5,6,-tetramino-，及び 1,4,5,8,-tetraminoanthraquinone( III), 又は 1-hydroxy一，及び 1-anilino-4,5,8,-triamjnoanthraquinone, 又は 1,4- §び 1,5-diaminoa-

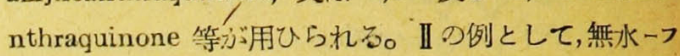
タル酸, 一クロルフタル酸, 一二トロフタル酸, 無水マ レレンン酸 (N) 等ゔ用ひられる。代表的染料として

を NVでアンル化し次D 棈造，化合物が述べられ てるる。

(Sice. pour 1'ind, chim. à Båle, U. S. P., 2,392,

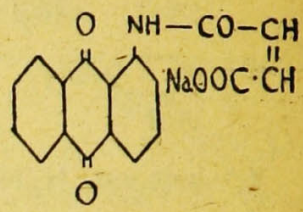

\section{3; C. A., 49, 2642 (1946)) (內木)}

重合物の染色に適するアン゙染料混合物 一般式 $\mathrm{R}_{1} \mathrm{~N}=\mathrm{NR}_{2}-\mathrm{N}=\mathrm{N}\left(\mathrm{CH}_{2} \cdot \mathrm{CH}_{2} \mathrm{OSO}_{3} \mathrm{H}\right)_{2}$ を有する化合物

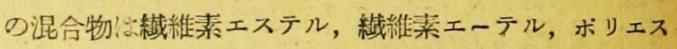
、テル類, ボリウレタン類つ䧱色に適する。となに $\mathrm{R}_{1}$ 区 $\mathrm{R}_{2}$ 水酸基, カルポン酸基, スルフォン酸基を有しな いペンセン系芳香核にして， $\mathrm{R}_{1}$ はニトロ基を有する。 之等化合物は 3-methyl-N,N-bis (hydroxyethyl) aniline の如き對稱性 Nーヂヒドロアルキル化された芳香 族アミンを, 1-amino-2-cyano-4-nitrobenzene 等の

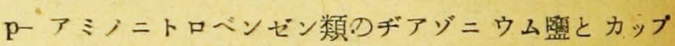
ルせしめ, 次でスルフォン化劑で處理して得られる。最 後にスルフォン化する代りに，カップリンクの前に Nー ヂヒドロアルキル化芳香族アミン類をスルフォン化する 子同樣の結果を得る。 (Soc. pour $1^{\prime}$ 'ind. à Bâle, U. S. P. $2,384,734$; C. A., 43, 1041 (1946)) (內木)

不溶性モノアゾ染料一般式 $\mathrm{H}_{2} \mathrm{NC}_{6} \mathrm{H}_{4} \mathrm{CONHR}$ (ここに CONHR はn一位又心 - $\mathrm{p}$ 位を占め, $\mathrm{R}=\mathrm{H}_{r}$ アルキル基, アラルキル基, アリル基, ヒドロ芳香基を 示し, これらのベンゼン核には更にアルキル基, アルコ オキシ基, アラルコオキシ基, アリルオキシ基，ハロゲ ンを有する)のヂアゾ化アミン類は, 2-hydroxy-carbazole-3-carboxylic acid, 3-hydroxydiphenylene-oxide 2-carboxylic acid 丑 3-hydroxydiphenylene-sul fide-2-carboxylic acid 等つアミド，アルキルアミド, アラルキルアミド，アリルアミド，シクロアルキルアミ ド類とカップリングせしめる。この反應の各成分はスル フォン基，カルポキシル基つ如き溶性化基を含またい。 (I. G., G, P, 741,358 ; C. A., 49, 1321 (1946)) (內木)

5一アミノー1,3ーベンゾヂオキン゙ールアン゙染料

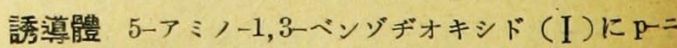
トロ・ハロゲンベンゾールを縮合せしめ，縮合生成物を 還元，ヂアゾ化及カッブリングを行つて儤れた色調と日 


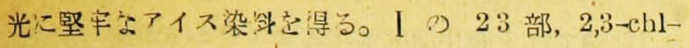
oronitrobenzene-sulfonic acid のナトリウム監 3.3部 を水 20 部に溶し, $\mathrm{CaCO}_{3} 1.3$ 部を加へ $24 \mathrm{hr}$ 還流下 飞熱する。後水 5 部, $\mathrm{NH}_{4} \mathrm{Cl} 3$ 部を加一, 更に亞鉆末 2 部を徐々に添加し $1 \mathrm{hr}$ 加熱す。溶液に $\mathrm{Na}_{2} \mathrm{SO}_{2} 0.1$ 部を加へ, 嘕酸 4 部芯加へて. 5- (2-3ulfo-4 aminophenylamino)-1,3-benzodixole (II) を沈澱せし市ら。 II 2.3 部を $25 \% \mathrm{HCl} 33$ 部と $\mathrm{SnCl}_{2} 0.3$ 部と還流 下に熱し，後水 25 部で稀釋し $\mathrm{Na}_{-} \mathrm{S}_{2} \mathrm{O}_{4}$ を含む $\mathrm{Na}-$ $\mathrm{OH}$ 溶液中に注ぎ, 生成物を濾別し少量つ籃酸を加一

5- (4-aminophenylamino)-1,3-3enzodioxole の整酸

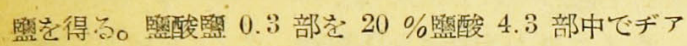
ゾ化し, 重曹で中和し豫め 3-hydroxy-2-naphthanilyde で處理された木棉苍浸染し，洗濯及 $\mathrm{Na}_{2} \mathrm{CO}_{3}$ で煮沸處 理し深青色に染める。 (American Cyanamid Co., U. S. P. $2,387,848$; C. A., 40, 1663 (1946)) (內木)

トリスア・染料 一般式 $\mathrm{HO}_{2} \mathrm{C}(\mathrm{HO})-\mathrm{R}-\mathrm{N}=\mathrm{N}-\mathrm{C}_{6}$ $\mathrm{H}_{2} \mathrm{X}, \mathrm{Y} \cdot \mathrm{NH}_{2}$ (こつに $\mathrm{R}=$ アリル基, $\mathrm{X}=$ アルキル ー, アルコオキシ基, $\mathrm{Y}=$ アルコオキシ基, 且つ水酸基 とカルボキシル基は相互にオルト位を占める)の化合物 の 1 モルに，アルカリ性中で 5,5'-dihydroxy-2,2'dian i robinaphtyl-7,7'-disulfonic acid (I) の 1 モル をカップリングせしめ, 次に生成せるヂスアゾ染料 1 モ ルと $\mathrm{C}_{\mathrm{u}} \mathrm{H}_{3} \mathrm{X}, \mathrm{XNH}_{2}$ (こに $\mathrm{X}, \mathrm{Y}$ は上述に同じ) のヂ アジ化合物 1 モルをカップリングせしめ, 繊維性物質の 染色に適するトリスアゾ染料を得る。例へば $3 \mathrm{~g}$ の 4-amino-2-methyl-5-methoxy-4'-hydroxy-3'-carboxy-1,1'-azobenzene そデアゾ化し，4.6 g の I を $\mathrm{Na}_{2} \mathrm{CO}_{3}$ 溶液中でカップリングせしめ, 生成染料を盟析谈別す。 更に之と $1.3 \mathrm{~g}$ の 1-amino-2-methoxy-5-methyl benzene のデアゾ化合物を $\mathrm{Na}_{2} \mathrm{CO}_{3}$ 溶液中でカップリン グを行ひ，生成染料穵監析濾過する。本染料は䕎色粉末 で, 硫酸に依り綠青色を呈し，水にとけて紫色を呈す。 木綿を直接に赤靑色に染め，更に銅監處理により木綿を 綠色に染め堅牢度を增す。(Soc. pour 1'ind. chim. à Bâle, B. P. 559,680 ; C. A., 4J, 469 (1946)) (內木)

\section{【高分子 化 合物】}

\section{ポリウイニル・イソブチルエーテルの性質と構}

造 ヴィニル・イソブチルェーテルを, プロパンを稀釋 㵯とし， $\mathrm{BF}_{3}$ を觸媒として，一 $-40^{\circ} \mathrm{C}$ て重合させると， 睃間的に反應してゴム狀の所謂オパノール0 を生成す る。 $\mathrm{BF}_{3}$ 觸媒の代りに, $\mathrm{BF}_{3}$ とヂェチルエーテルの複 化合物を觸媒として，一 $40^{\circ} \mathrm{C}$ て触媒を滴下寸る樣にす
ると，反應はゆるやかに進行し，重合物は結晶質である。 此等 2 種類の重合物に就て, 分別試瞼, 溶液粘度, 粘秱 性, 硬度, 䓡可塑性, 電氯絕綵性, 溶解性:等つ測定及び $\mathrm{X}$ 線迥折による棰造決定を行つだ。オパノール C は, 結晶質の PVI と異なり重合度ゔ極めて均一て岕るが， 兩者つ性澌つ相違は重合度つ大小や各の分有に基く事よ りも, 空問異性に基くものと考へられる。オパノール 生成つ場合は反應う㯺間的に行はれる爲, 隣接したイソ ブトオキシ基方゙分子鎻の一フう並んで位置する可能性を 生じ，この立體障害に基づき，分子鋇ゔ曲り結晶化方゙妒 げられるものと思われる。(C. E. Schildknecht, S. T. Gross, H. R. Davidson, J. M. Lamiert and A. O. Zoss, Ind. Eng. Chen., 40, 2104 (1949)) (淺原)

Relativi-Orosslinks(架橋度) と不飽和度との關係 $\left(\begin{array}{c}\text { (原容皘) } \\ (\text { 原容積 })+(\text { 容積慒加 })\end{array}\right)^{5 / 3} \times 1000$ をRelative-Crosslinks と定義し，分別したブチルゴムを $265^{\circ} \mathrm{F}$ で加統 した後，メチルェチルケトンで抽出し， $25^{\circ} \mathrm{C}$ でシクロ

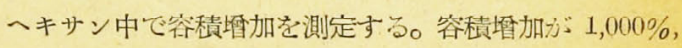
郎ち Relative-Crosslinks=18.2 になる時間を t とする と, 加硫促進劑として Tetramethylthiuramdisulfide を用い庆場合は， $\mathrm{t}=\mathrm{C} / \mathrm{n}^{1.8}$, Benzothioxylmonocyclohexylsulfenamide を用いた場合には $\mathrm{t}=\mathrm{C} / \mathbf{n}$ なる實騟

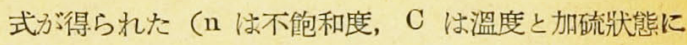
關係する恒數)。叉モデル的な考察から理論式として $\mathrm{t}=\frac{\mathrm{C}}{\mathrm{n}^{2}-\mathrm{k}\left(\mathrm{n}^{3}-\mathrm{n}^{2}\right)}$ なる關係老求めてるる(kは比例 常数)。(R. L. Zapp, Ind. Eng. Chem., 49, 1508 (19 48)) (淺原)

クロロプレンからの彈性體 2-クロロ $-1,3-フ ゙ タ$ ヂエンを, ブタヂエンの場合の 25 倍の速さで, クロロ プレンの場合より稍々退い民寉速度で 75〜90\%の重合 率で乳化重合する。このるのはクロロプレンと翼なり, モノヴィニル化合物と廮い割合で, 共重合する性質ゔあ る。クロロプレシ重合物は他のハロプレン重合物と異な り,ブタヂェン重合物に似て緊張狀態て無定形性であり 電氣的性質い天然ゴムに近く, 燃然速度も運い。加硫物 は 400 500\%の伸度に於て, 引張强度 2800 3000 $\mathrm{lb} / \mathrm{n}^{2}$ で，耐寒性，而注油性が良好である。此に對して 共重合體は、メチルメタアクリレート，ヂメチル・（ヴ ヘニルエチニル)・カービノール，スチロール，アクリル ニトリル等と樂に作られ，3～15\%之等Dモつヴィニル 化合物を加へると性質は向上する。特に $5 \%$ カードノー ル, 凤は・10\%スチロールの割合で共重合したるのは性 質が良好である。アクリルニトリル共重合體は而油性が 
特に良好で，15\%入れると耐寒性す優れてるる。30〜40 \%になると,而油性は一層向上するゔ耐寒性は低下する。 この型の加硫物の引張强度は 4,500 5,000 lb/in² です る。 (W. E. Mochel, L. F. Salisbury, A. L. Barney, D. D. Coffmann and C. J. Mighton, Ind. Eng. Chem., 40, 2285 (1948)) (淺原)

合成樹脂や皮膜の原料となる孚樎合物 改良さ れた乳酸縮合物は皮膜として與味ゔある。乳酸を溶劑中 で加熱すると脫水，エステル化ぶ起つてポリ乳酸となる が水に弱く脆い。ボリ乳酸をアルコール，アルデヒド，

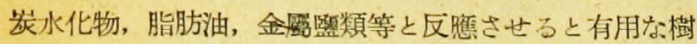
睧となる。最も有用なのは乾性油と觸媒とを加へて加熱 して得られる柔軟な彈性のある整硬化性樹脂で, ラッカ 一として强靶な耐水性の皮膜を作る。例入は脫水乳酸 130 分, 植物油 60 分, 無水マレイン酸 5 分, フマール 酸万分, 觸媒として活性化したボーキサイト 2 分を混じ $265 \sim 280^{\circ} \mathrm{C}$ に加熱して得た樹脂を $20 \%$ キシレン溶液 としてラッカーに用いる。又ボリ乳酸を可溶性の金屬蝇 類上反應させれば，殆んど乳酸のみからなる樹脂ぶ得ら れ，保蒦裝飾用皮膜に適している。（P．D．Watson，

Ind. Eng. Chem., 49, 1393 (1948)) (山下)

鹽化ヴイニル;醋酸グイニル樹脂に對する可塑劑 の效果 篮化ヴィニルー醋酸ヴィニル樹脂に對する 99 種の可塑劑の效果を記した表を揭げて岕る。可塑劑の量 を變へて，その效果は $10,25,40^{\circ} \mathrm{C}$ て $1000 \mathrm{lb} / \mathrm{in}^{2} に$ 於ける伸度で比較した。又揮登損失, 油抽出物, 水抽出 物, 屈曲溫度, 樹脂との適合性を調べた。各可塑劑つ化 學組成, $20^{\circ} \mathrm{C}$ 粘度及び比重をあげてある。可塑劑の揮 発損失は試驗片の厚さに逆比例し, 又 $7^{\circ} \mathrm{C}$ 上昇与ると 2 倍になる。損失量山露出時間に比例する。條件の異つ た場合の損失を求める實驗式を提案している。可塑劑の 割合み゙變化しないためには，蒸氣熙ゔ低く化學的に安定 なことぶ必要條件である。 (M. C. Reed, L. Connor, Iud. Eng. Chem., 40, 1414 (1948)) (山下)

\section{アクリル酸及びメタクリル酸のアルキルエステ} ル單量體と重合體の性質 種々のメタクリル酸アルキ ル，殊にアルキルエステルの製法と物理的性質を記して

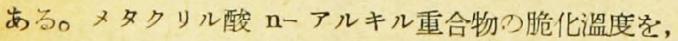
アルキル基つ炭素數に對してプロットするとアアクリル 酸 nーアルキルの場合と同樣な曲線门得られる。メタク リル酸 $\mathrm{n}$-アルキル重合物の脆化溫度は, ドデシルエス テルまでは分子量つ櫭加するにつれて減少し, 次て㙁加。 ナる。ドデシルエステル重合物の脆化溫度は $-34 \mathrm{C}^{\circ}$ で,

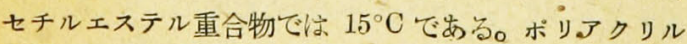

酸アルキルの最初の 8 員及びボリメタクリル酸了ルキ ルの最初の 12 員では, 脆化溫度はアルキル基の炭素數 の對僌に對して直線的に變化する。硬度の基準となる Willams のブラストメーターの值は,ポリアクリル酸ア ルキルでは略ノニルェステルに至るまで分子量の增加に つれて減少する。アクリル酸メチル乃至ノニルの間では ブラストメーターの測定値は脆化溫度に比例する。ポリ メタクリル酸ブチル，アミル，オクチル，デシル等でる ブラストメーターの測定值はアルキル基の長さの䝬加に つれて減少する。この場合もブラストメーターの値は脆 化溫度に比例する。（C. E. Rehberg and] C. H. Fisher, Ind. Eng. Chen, 4j, 1429 (1948)) (山下)

ヴィニヨンN樹脂及び纎維 ヴィニヨン $\mathrm{N}$ は㗨化 ヴィニルとアクリロニトリルの共重合物で, 從來の圙化

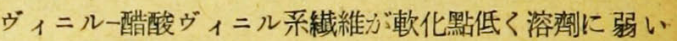

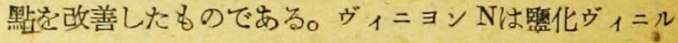
$56 \sim 60 \%$ を含む乳湢重合物で, $0.2 \%$ チクロへキサノン 溶液の比粘庤 $0.25 \sim 0.30$, 比重 1.30 である。流動性 ガかなので成型品には適さない。溶劑に溶け難いためラ ッカーとするの心制限されるぶ而溶性の皮膜を作る。此 の組成のヴィニヨンNはあアセトン,チクロへキサノン， ヂメチルフォルムアミドには溶けるが他の溶劑には殆ん ど溶けない。可可塑劑とも混合し難く，トルエン・エチ ル・スルフォンアミド, テトラヒドロフルフリル・フタ レート等ぶ使用し得る。軟化點は $85^{\circ} \mathbf{C}$ であるぶ, 150 ${ }^{\circ} \mathrm{C}$ で 2 時間處理すると $90^{\circ} \mathrm{C}$ となり， $2 \%$ の $\mathrm{ZnO}$ を 豫め加へて熱處理すれば $98^{\circ} \mathrm{C}$ となる。 $25 \%$ アセトン 溶液加紡系して强度大, 不燃性, 化學抵抗大, 吸水小 なる優秀な瀻維を得る。（E. W. Rugeley, T. A. Feild and G. H. Fremon, Ind. Eng. Chem., 49, 1724 (19 48)) (山下)

\section{ドイツに於けるポリエチレンイ ミ；の製造と用} 途 I. G. の Ludwigshafen では月産 $5 \sim 6$ tのポリエ チレンイミンを製造して，主に紙や瀻維の耐水處理に用 ひていた。エチレンイミンの製法はモノエタノールアミ

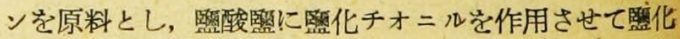
エチルアミンとして, 冷苛性ソーダ水溶液で脱整酸する 方法と， 0 -ヂクロロベンゼン溶液中で加熱して, 硫酸盟 として菏性りーダ水溶液で處理する方法とある。 $0.1 \%$ の $\mathrm{CO}_{2}$ を加へて重合させる。ポリエチレンイミンの 50 \%水溶液は褐色の粘䅕な液體である。パルプの耐水處理 には 1〜2\%のボリエチレンイミンを $3 \sim 5 \%$ 水溶夜とし て加へる。繊維の耐水處理にはエチレンイミンをイソシ ヤナートと重合させて尿素置換體とし, 織維素の水酸基 
と反倠させる。イソシャナートとしてはステアリルイッ シヤナート, ヘキサメチレン・ヂイソシヤナート,ヂフ エニルメタン・ヂイソシャナート等を用いる。人絹, 羊 毛つ耐水處理に有效である。(Mod Pl., 26, 130 (1948), (山下)

カゼイン及びカルバミド・カゼイう カゼイン及ひ カルパミド・カゼインはフォルムアルデヒドて前處理し て成型粉末とし, 强度大なる成型品空作ることが出來る。
有機可塑劑と共に最高 $10 \%$ の水を成型粉に加へて成型 すると，普通の狀態では形の崩れないるのが得られる。 カゼインを化學處理してカルパミド・カゼインとすれば 蛋白質の吸水性は著しく改善され, 然も接着力は變化し ない。カルパミド・カゼインはブラスチックス以外の分 野にも發展性方゙ある。(N. J. Hipp 他, Mod. Pl., 26, 205 (1948)) (山下)

\section{業 界 情 勢}

アルコールの昭和 23 年度生座害績 本年度最初 の生產計畫は $25,000 \mathrm{kl}$ を目標とせられしも, 第 1 及 び第 2-4 牛期とも原料及び不炭の入手難に加 万るに工 場の大修理を要するものも續出して, 豫定の生產量を遥 に下㛠りしも，第 $3-4$ 牛期よりは糖蜜の輸入及び生甘 藷の出迴期となり，加らるに工場の修理も成りて一段と 活氣づき, 前牛期の不振を取戻して次表の如き好結果が 得られた。

\section{各隌工局地區别生産赛綪 (紧位 $\mathrm{k} l$ )}

\begin{tabular}{|c|c|c|c|}
\hline 地 區 & 無水アルコール & 合水アルコール & 計 \\
\hline 札 幌 & - & $1,744.5$ & $1,744.5$ \\
\hline 東 京 & 755.6 & $5,271.8$ & $6,027.4$ \\
\hline 名古屋 & - & $5,506.9$ & $5,506.9$ \\
\hline 大 阪 & - & 394.6 & 394.6 \\
\hline 饃 島 & - & $2,287.9$ & $2,287.9$ \\
\hline 國 & - & $1,667.7$ & $1,667.7$ \\
\hline 福閏 & 693.2 & $10,131.8$ & $10,825.0$ \\
\hline 計 & $1,448.8$ & 27.005 .2 & 28,454 \\
\hline
\end{tabular}

(北胳)

\begin{tabular}{|c|c|c|c|}
\hline 別 & 21年(t) & 22 年(t) & 23 年(t) \\
\hline 油 & 9,503 & 4,365 & 7,263 \\
\hline ワニス系鋫料 & 1,571 & 1,844 & 4,420 \\
\hline 船 底 望一料 & 364 & 1,026 & 1,500 \\
\hline 酒 精 染 料 & 217 & 620 & 950 \\
\hline 水 性 望 料 & 972 & 1,152 & 2,000 \\
\hline ラッカ & 1,307 & 1,579 & 5,000 \\
\hline 稚 & 1,701 & 610 & 1,830 \\
\hline 電氣絕秝塗料 & 1,704 & $2,23 \dot{3}$ & 3,924 \\
\hline 合 & 17,840 & 13,429 & 26,893 \\
\hline
\end{tabular}

戰後の生產は大部分進駐軍關係に需要せられた。23年 度に入つてから，油脂その他の原料輸入が許可されたの で，生產上帠に轉じたことは喜び耐えない。

戰後生產の低下した有力な原因の1つは，本工業わ゙そ の主要原料の大部分を海外に仰いでいるためである。輸 入原料を極力節約し製品量を增加せしめる必要から，エ マルジョン塗料の生座ゔ計畫されている。從來の油へィ ントは原料油を35\%8使用するぶ，エマルジョン塗料 では乳化劑と水とを用いることにより,油の使用量を 20
醋酸等の昭和 22 年度と同 23 年度生産害績此較（單位 $\mathrm{t}$ )

\section{醋酸エステル頑}

\begin{tabular}{|c|c|c|c|c|c|c|c|c|c|c|}
\hline 年次 & 醋 酸 & $\begin{array}{l}\text { 無水 } \\
\text { 醋酸 }\end{array}$ & $\begin{array}{l}\text { P七 } \\
\text { ry }\end{array}$ & $\begin{array}{l}\text { プタ } \\
\text { ール }\end{array}$ & エチ & $\begin{array}{l}x \\
\text { u }\end{array}$ & $\begin{array}{l}\text { ブチ } \\
\text { ル }\end{array}$ & $\begin{array}{l}r: \\
ル\end{array}$ & $\begin{array}{l}\text { フー } \\
\text { ゼル }\end{array}$ & $\begin{array}{l}\text { 醋 酸 } \\
\text { ビニル }\end{array}$ \\
\hline 22 & 5,805 & 429 & 689 & 173 & 1203 & 308 & 227 & 20 & 6 & 155 \\
\hline 23 & 11,120 & 843 & 1039 & 670 & 1956 & 729 & 654 & 22 & 15 & 442 \\
\hline
\end{tabular}

\%以下に節約することぶ出來る のである。

フタール酸レジン湬料も油脂 節約の見地から望ましいゔ，無 水フタール酸とグリセリンの供 給不足のため生座はおぼつかな い。尿素樹脂泾料も未だ進展し
本邦の鉒料工菜の現頃 昭和 $5 \sim 6$ 年は年產 5 萬 $\mathrm{t}$ 位, 同 $13 \sim 16$ 年方最高で年產 11 萬 $\mathrm{t}$ に達した。戰 後の生举狀況は次表の通り低下している。但し 23 年は 計畵である。
ていない。

經濟復與計富の最終年度の 28 年度 10 萬 $\mathrm{t}$ 生座に必 要な原料は次表の通りであるが, 油脂, 樹脂を゙初め石油 系溶劑等の榆入に俟つべき原料が多く，國內で自給し5 